\title{
Building a transnational movement for family planning: 1928-70
}

This chapter delves into the many ways in which British women doctors pressed for the development of an international movement for birth control and family planning, from the first attempt in 1928 to create an international organisation to the establishment of the International Planned Parenthood Federation in 1952. ${ }^{1}$ In addition, this chapter pushes the transnational approach even further by showing how the circulation of actors and knowledge from Britain to France eased the creation of a French family planning movement and family planning centres. As shown in Chapter 3, from the mid-1920s, British female doctors were decisive agents of the medicalisation of birth control at international conferences. These conferences gathered scientists, doctors and activists - the majority of whom were male - and advocated the use of birth control, but on different grounds. Alison Bashford has argued that population, food security and world resources were central motives behind famous scientists' participation in this movement. ${ }^{2}$ Women were also present, and chief among them was the American birth control activist Margaret Sanger. The British women who took part in these international conferences were strongly feminist and envisaged birth control as a means of improving women's health. At the 1930 Zurich International Conference on Birth Control, female British doctors, alongside female German, Swedish and American doctors, shaped the debate in favour of the medicalisation of the issue. They drew on their practical experience acquired at national levels to move away from moral considerations of birth control, and instead concentrated on applied scientific knowledge of contraceptive methods. This experience made them skilled in debating the issue at international levels, reinforcing their expertise and positioning them as experts on these issues. 
British women doctors were also instrumental in the creation of the first international movement specifically dedicated to spreading the 'gospel of birth control' in the interwar years, namely the Birth Control International Information Centre (BCIIC). After the Second World War, this international campaign for birth control spawned the International Planned Parenthood Federation, in which contraception was formally established as a medical issue. In the reactivation of this movement, British women doctors assumed prominence, along with their Swedish, American and Dutch colleagues. Drawing on the proceedings of international conferences on contraception and family planning; the archives of the Medical Women's Federation, the Family Planning Association, and the Mouvement Français pour le Planning Familial; and female doctors' publications, this chapter demonstrates the agency of British female doctors from 1930 onwards at the transnational level. In doing so, this chapter first looks at their contribution and their role in the first attempt to create a Birth Control International Information Centre, before analysing their contribution to setting up the International Planned Parenthood Federation (IPPF). Finally, a discussion of the influence of British women doctors on French doctors and the French movement for family planning closes this chapter.

\section{Going international: the Birth Control International Information Centre}

As briefly explained in Chapter 3, following the 1927 Geneva conference, and under the leadership of Margaret Sanger and Edith HowMartyn, in 1928 a first attempt was made to create an official organisation for people working on birth control. It resulted in a London-based centre, the Birth Control International Information Centre, aimed at 'disseminating applied knowledge on contraception' ${ }^{3}$ through a network of women physicians, social workers and birth control activists. The centre provided information, literature, and updates on the 'latest and most hygienic measure known' ${ }^{4}$ for avoiding pregnancy. Besides spreading information, the centre collaborated with birth control clinics in London to offer training in contraception to foreign doctors; this teaching was under the leadership of Helena Wright. Her expertise and experience in pushing for training facilities in Britain (see Chapter 1) made 
her the ideal person to take up this new work, and it illustrates how Wright easily navigated between the national and international spheres, using the skills and knowledge she acquired at both levels to advance the cause of birth control.

Numerous leaflets presenting the work of the centre called attention to the fact that 'urgent appeals from doctors and social workers in all parts of the world' had reached the centre. This shows how calls for birth control advice originated from the grassroots activism of people in touch with the needs of mothers, as well as mothers themselves, who 'begged' the centre 'to help them with knowledge and advice for limiting and spacing their family.' The centre had correspondents in many countries, such as Poland, Spain, South Africa, Japan, Norway, Sweden, Finland, Soviet Russia, Canada, India, Japan, China and France. These correspondents testify to the onset of an international movement. Interestingly, the French correspondents who were invited to present the situation in France to members of the centre were not native French, but migrants who lived in France; these included Susanna Green (1855-1937), a British-born educator who lived in France, and the Dutch writer, traveller and mistress of H. G. Wells, Odette Zoé Keun, who lived with Wells in Grasse. Both visited the Birth Control International Information Centre and spoke about the French situation. They also received training in birth control. ${ }^{6}$ In addition, Green distributed leaflets provided by the BCIIC to French public health officials. The fact that it was non-French individuals who advocated birth control is revealing of the repressive context in which many French individuals found themselves.

Finally, the centre organised international conferences on birth control. As explained by Lord Horder when opening the 1933 London conference, organised by the BCIIC on the subject of birth control in Asia, the main goal of the centre was 'missionary, that is to say, it aims at making known as widely as possible, and ... in as many countries and languages as possible, the gospel of birth control.' The term 'missionary' evidences the legacy of colonialism and the view held by BCIIC on the leading roles of its members in educating other countries. This form of knowledge transfer implies an assumption of superiority on the part of BCIIC members. Representatives of Japan, India, ${ }^{8}$ China and Ceylon were present. Helena Wright opened the session on the 
practical problems of contraception in the East. Lord Horder, introducing her to the audience, emphasised her expertise in birth control in Britain but also stressed the fact that she had lived in China and had 'studied the problem there,', thereby portraying her as both a national and international expert. Wright started by presenting what she considered to be the essential element for setting up an international movement for birth control, namely the fact that the input should come from within each country. She adopted a stance that she would keep while reactivating the international movement of planned parenthood after the Second World War: while acknowledging that financial and advisory help could prove fruitful, she emphasised that 'control of the movement ought to be in the country in which the work is taking place. ${ }^{10}$ This position would later clash with that of Margaret Sanger, as I will show in the following section. To foster the development of national birth control movements and centres, Wright explained that she had already trained a female Chinese doctor in contraception: Dr Ling, who was willing to open a training centre in Peking. Wright's strong case in favour of national self-determination to develop birth control infrastructures in foreign countries was picked up again and made central by Edith How-Martyn while closing the conference, showing how influential Helena Wright's ideas were. The movement was very much a Western movement, however, attempting to spread its own views to other countries by educating members about Western values and methods.

Between 1930 and 1940, in a context of fear of declining fertility, supporters and militants for birth control foregrounded the positive aspects of their work. Besides relying on arguments connected to the health of the mother - where eugenic, neo-Malthusian and feminist arguments were invoked at international conferences - they increasingly referred to 'planned parenthood' alongside 'birth control', a way to stress the right of parents to decide the size of their family as well as the individual welfare of the child. For instance, the 1936 leaflet advertising the BCIIC distinguished between birth control in the Western world and 'uncontrolled fertility elsewhere,", and epitomised birth control in modernity. Accepted by most 'progressive people,' ${ }^{12}$ birth control was 'one of the greatest achievements of modern science. ${ }^{\text {13 }}$ While parental health, especially that of mothers, had been an essential argument for the legitimation of the use of birth control in the previous 
decade, individual responsibility for the well-being of the child was central in the leaflet:

By making the birth of a child dependent on foresight and deliberate choice, birth control has enabled parents to exercise a civilised regard for the rights of the children whom they voluntarily bring into the world. The knowledge of this power to control conception has heightened the self-respect of men and women, and immensely increased their sense of personal responsibility for the good management of their own lives, and for the welfare of their children. ${ }^{14}$

Framed in the rhetoric of rationalisation typical of the post-Depression era, when the UK and US encouraged economic planning, this quotation encompasses all the propositions that would constitute the motto of the IPPF: the parents' responsibility to decide on the size of their family, the emphasis on voluntary and rational child-rearing, and, most importantly, the right of children to be wanted and to have a good life. ${ }^{15}$ The concept of planned parenthood aimed to improve the environment in which children were born and raised so as to make every child a wanted child. This idea opened up the path to a new medical research field focusing on infertility and harmonious matrimonial relationships as instrumental to good child-rearing. Female doctors invested in these new fields in great numbers, as we saw in the previous chapter.

This international movement was halted for a decade by war, before resurfacing afterwards in 1946. The prevailing context was no longer one of declining fertility, but of the growth of the global population and of an intensive population explosion in Asia, Latin America and Africa, raising fears of shortages of food and resources. ${ }^{16}$ As the following section shows, women doctors again played a pivotal role in rebuilding and expanding this international movement.

\section{Women doctors as creators of the international movement for planned parenthood}

Women doctors were instrumental to the creation of the international movement for planned parenthood after the Second World War. Sweden hosted the first postwar international Conference on Sex Education, Family Planning, and Marriage Counselling in Stockholm in 1946, organised by Elise Ottesen-Jensen from the National League for Sex 
Education, who was also present at the 1930 international conference. ${ }^{17}$ Ottesen-Jensen invited Joan Malleson to attend the conference as a representative of the FPA. ${ }^{18}$ During the conference, a resolution was passed on the need to recreate an international association of family planning and population professionals. This call quickly came to fruition. With the financial support of Margaret Sanger, and under the auspices of the FPA, an international congress on Population and World Resources in Relation to the Family was held in Cheltenham, Britain. It brought together scientists from more than twenty-two different countries. Elise Ottesen-Jensen and Margaret Sanger were both present. Several British women doctors participated in the conference and played a pivotal role in its organisation; Wright was the chairwoman of the organisation committee. She described this role as 'a key position that has to be handled very technically and carefully since you mustn't frighten the people around you whose ideas are smaller. ${ }^{19}$ In other words, the position required the negotiating skills that Wright acquired in her fight for birth control in Britain. She first contacted the leaders of the birth control movement in China, the US, Sweden and Holland, and she later remembered: 'Quite early here was the chance of making the beginning of an international link but nothing had to be said yet. ${ }^{20}$ At the opening of the conference she described the aim of this international meeting: the conference would result in no less than 'wellconsidered, powerful action which will eventually change the conditions of the world. We cannot have a bigger aim than that, and we have to prove ourselves worthy of it. ${ }^{, 21}$

Among the chairwomen of the sessions were Lady Denman, chairwoman of the FPA; Wright; Margaret Jackson, medical officer of the Exeter and District Women's Welfare Centre, which she had also contributed to setting up; and Malleson. These women had all been present at the international conference on contraception held in Zurich in 1930. Thus, they were central to the continuity of the movement for birth control and its reconfiguration into the planned parenthood movement. ${ }^{22}$ Wright would later explain that she was very well suited to being in charge of the organisational aspect of the conference, since she was a curious personality because [she was] essentially international and [she] got to know these people in Zurich. ${ }^{23}$ They were not exceptions in Britain; several male scientists, such as London's eugenics leader, Carlos Paton Blacker, who intervened in the 1930 Zurich conference, 
were also present. Male scientists still held highly visible positions in the conference and were in the majority as speakers; they included Abraham Stone, vice-president of the Planned Parenthood Federation of America; Professor Whelpton from the Scripps Foundation for Research in Population Problems at the University of Miami; and Sir John Boyd Orr, Director-General of the United Nations Food and Agriculture Organization. This situation reflected the need to gain recognition from the international community.

While Wright was supposed to chair the last session of the conference, she ceded her chair to one of her famous American male colleagues, Frank Lorimer, Professor of Sociology at the American University in Washington. Her retreat is symptomatic of the work carried out by female doctors: practical work that occurred behind the scenes, though it was essential to organising such an international network. Although women doctors' roles were less visible, they were highly influential since they were the ones who organised the conference and decided who to invite.

Only one French scientist was present, Jean Sutter from the National Institute of Demographic Studies. He presented the pronatalist policy in France, explaining that 'all French Governments are opposed to contraceptive propaganda, because of the state of our population, and for fear of accelerating the present trend and having a population which will decline, with incalculable speed, until it totally disappears. ${ }^{24}$ This position clashed with the increasing recognition of the importance of family planning underlying the conference. Consistently, the session's chair was quick to remind him that it was not merely a matter of family limitation; to many people, the object of providing contraceptive information was to give women freedom to decide for themselves the number of children that they wished to have. ${ }^{25} \mathrm{He}$ drew attention to the idea of planned parenthood as disconnected from the natalist vision and encompassing the well-being of the family: 'the problem is not one of the large families but of happy families, and happy families could be attained only through freedom of choice and desire on the part of the parents themselves. ${ }^{26}$ Helena Wright recalled that, for France, they had chosen 'the wrong leader but we had to deal with it. ${ }^{27}$

The resolution taken during the conference underlined the fact that 'wanted children who can be given a reasonable standard of living are the first essential for the building of a happy and stable family life. ${ }^{.28}$ This 
led to the creation of a provisional international committee, made up of British (Wright), Dutch (Dr Conrad van Emde Boas), Swedish (Ottesen-Jensen) and American (Margaret Sanger and Abraham Stone) delegates; it was set up in London, due to the efforts of Wright and Margaret Pyke, secretary of the FPA, in an office provided by the Eugenics Society. The purpose of the committee was to exchange information and foster research on family planning - i.e. contraception, fertility and sub-fertility - by providing contraceptive information to clinics and doctors. To this end, it established contact with family planning organisations in over twenty countries. Finding a name proved difficult as soon as the idea of formalising the movement arose. Helena Wright remembered the complexity of finding a common ground between these personalities as they met for several hours each evening of the Cheltenham conference:

We began to have long evening meetings. The personalities were so different. Conrad had to disagree with everything. Three and four evenings, three to four hours, we, four countries' leaders, beckoned, unable to find words. We had the idea, in our minds it was quite clear, but to find a word in English that would be acceptable to all personalities was our first experience of how difficult that was, but we succeeded. ${ }^{29}$

The correspondence between Helen Donington, secretary of the provisional centre, Margaret Sanger and Helena Wright attests to the conflicting views on the direction that the organisation should take. The common aim rested on the need to appoint an advisory board in each country, made up of distinguished and high-level individuals, to give status to the organisation as well as giving 'access to valuable data, ${ }^{30}$ on the individuals in need of this service. In the British case, the names put forward were those of Lord Horder, physician and president of the Eugenics Society; Julian Huxley, the evolutionary biologist; and Sir John Boyd Orr, doctor, biologist and Director-General of the United Nations' new Food and Agriculture Organization (FAO) and a future Nobel Prize winner (1949). Margaret Sanger encouraged the British branch to have 'several population men' on its committee, reflecting her desire to orient the work of the organisation towards this subject.

Sanger was convinced that in order to gain support from American fundraisers the organisation needed to distance itself from the resolution taken at Cheltenham, since 'there is nothing in the resolution 
relative to world resources and a very great deal is said about family planning, marriage counselling and other aspects of the movement, which in the opinion of many people here, is not as important a need in the educational field as the subject of population and world resources. ${ }^{31}$ But while agreeing that close collaboration with eminent individuals working in the field of food resources was to be encouraged, British members were of the opinion that fundamental research on this topic, as suggested by Sanger, remained beyond the scope of the organisation and they would prefer to see this type of research undertaken by other bodies specialising in the area, such as the UN or UNESCO. ${ }^{32}$ Indeed, as underlined by the British members, as a voluntary body, the organisation was free from 'political and religious pressure', and they were reluctant to 'burden themselves with this area of work'. In addition, the British members, Helena Wright and Margaret Pyke in particular, acted as mediators in the controversial issue of naming the international committee. Tensions arose between Margaret Sanger, a strong proponent of population control who suggested the name 'International Population Planning Committee', and the Swedish, Dutch and British members, who were in favour of addressing the sexual needs of individuals and were sensitive to the diverse attitudes towards sexuality among the peoples of the world. Eventually, they settled on the International Committee on Planned Parenthood (ICPP). ${ }^{33}$ The ICPP helped to organise an International Congress on Population and Family Planning in India 'to begin definite preparations for a permanent world organisation. ${ }^{34}$ This conference resulted in the creation of the IPPF, to which Sanger was appointed honorary co-president.

The headquarters of the ICPP and later IPPF was in London and functioned as a central hub for help and advice on family planning for all member countries. At Wright's instigation, a medical subcommittee was formed in 1954 with the mission of collecting and circulating information on family planning services and setting standards of organisation for clinics. ${ }^{35}$ Headed by Jackson, it aimed at 'reaching international agreement on tests and standards for contraceptive products. ${ }^{36}$ The headquarters also hosted training courses on contraceptive techniques and received the visit of a French delegation, as made clear in the first report of the IPPF. ${ }^{37}$ To sum up, the federation again relied on women doctors to organise and provide the training of foreign members. Wright also travelled around India after the Bombay conference to give lectures 
and training in contraceptive techniques. In 1960, she undertook a teaching tour in Poland, as did Cecily Mure, of the Walworth Branch of the FPA, in Pakistan. ${ }^{38}$ From 1963 onwards, Jackson, Wright, Eleanor Mears (1917-92, a gynaecologist, member of the MWF and medical secretary of the FPA) and Mary Pollock (clinical assistant at the Gynaecological and Fertility Department of the Royal Free Hospital) were members of the medical committee of the IPPF region for Europe, the Near East and Africa, testifying to the key roles they held in the IPPF. ${ }^{39}$ Women doctors also circulated international work and contributed to the publication of handbooks. Mears edited a British issue of Babies by Choice or by Chance by Alan Guttmacher, the president of the IPPF. Wright, Jackson and Mears all wrote chapters in the Medical Handbook on Contraception, published by the IPPF in 1964. This handbook reviewed the latest advances in contraceptive methods and included contributions from international doctors.

\section{Framing planned parenthood as a human right}

This section analyses how planned parenthood became increasingly promoted as a basic human right, thanks, in part, to women doctors. This happened in the postwar context of the growth in discourse around 'human rights' (e.g. the Universal Declaration of Human Rights, 1948) and at a time when this concept became part of the language of everyday life and a marker of 'modern civilisation'. At the 1948 Cheltenham conference, four sessions were dedicated specifically to family planning. Study groups were also organised around the medical aspects of family planning, such as sub-fertility, sex education and marriage guidance, revealing the new stance of the family planning movement. In one of the family planning sessions, Jackson underscored the need for a different approach to family planning according to particular national priorities - for instance, encouraging birth regulation in Britain but birth limitation in parts of the world facing overpopulation. ${ }^{40}$ This call would form the basis of the policy of the IPPF. The IPPF's country-specific approach would increasingly be recognised as the 'proper' family planning policy by policymakers all over the world.

A constitution for the new federation was finalised at the Fourth International Conference in Stockholm in 1953. It stressed knowledge 
of contraception as a 'fundamental human right." ${ }^{41}$ By referring to contraception as a 'human right', this constitution pinpointed the international dimension of this right, beyond the individual rights of Western citizens. It reflected the view that birth control had to become an international priority and that every human should consider birth control and plan their family accordingly. In addition, this rhetoric diluted the feminist perspective usually linked with birth control, in favour of a more 'gender-neutral' approach to family planning, where gender specificities were less visible. Framing birth control as a human right was also a means to ally politicians and governments, who might plausibly have been reluctant to support a feminist narrative. Another aim was to stimulate appropriate research in the following subjects: 'the biological, demographic, social, economic and eugenic implications of human fertility and its control; methods of contraception; fertility, sub-fertility and sterility; sex education and marriage counselling,, ing the concept of 'planned parenthood'.

This cultural script of human rights became predominant, and it was found at the international conference in Vienna in 1968, organised by the International Women's Federation and entitled The Hungry Millions, a clear sign that family planning was again being seen through the lens of the 'population bomb'. Contemporary fears of population explosion and food shortages permeated all dimensions of the proceedings of this conference. Female medical doctors presented family planning as 'a basic human right' and underlined the need for medical responsibility in 'participating in a variety of methods of family planning which need to be carefully selected for their applicability to the people for whom they are advised. ${ }^{43}$ Education, rather than imposition, was presented as the best way of spreading family planning. These positions greatly reflected those of the IPPF, strengthening the cultural script spread by the federation. As pointed out by Nikolas Rose and Alison Bashford, individual freedom was the cornerstone of reproductive rights, and planned parenthood was to be achieved 'through the self-government of individual women: the exercise of a "universal" right to reproductive choice. ${ }^{44}$ Female doctors, among them Wright and Jackson, were thus instrumental in creating an international movement of planned parenthood after the Second World War and providing training to members from different countries in order to make 'this universal right' of 
contraception widely available. Their role was not only general, working in the larger international sphere; they exercised a great influence on French doctors in particular.

\section{British women doctors' influence on French family planning centres (1950-70)}

In 1956, more than thirty years after the 1920 law was enacted forbidding the dissemination of contraceptives and information on contraception, the French female gynaecologist Marie-Andrée Lagroua Weill-Hallé and the housewife Evelyne Sullerot, along with women from the middle and upper classes, created the Association of Happy Motherhood (Maternité Heureuse). This association was set up following the widely publicised 'Bac affair', where a young married couple was accused of accidental manslaughter following the death of their fifth child. The trial revealed that the mother was completely exhausted after five consecutive pregnancies. During the trial, witnesses were called to defend the couple, Lagroua Weill-Hallé being one of them. Ignorance about contraception was therefore perceived to be the reason behind this dramatic case. The fact that its founding members were all mothers gave the association respectability at a time when promotion of birth control was still illegal. Its aim was to fight ignorance, considered to be the main cause of backstreet abortions and unhappiness within marriage, through the spreading of information on contraception to its members thanks to the collection of scientific research on this topic carried out in France and abroad. The association was renamed the French Family Planning Movement (le Mouvement Français pour le Planning Familial) and became a national branch of the IPPF in 1959.

In 1967, after more than fifteen years of lobbying and intense activism from members of the movement, the Neuwirth Law legalised contraception in France. The history of the liberalisation of contraception and abortion has received much attention from historians. ${ }^{45}$ However, what remains overlooked is the influence of the international network on the establishment of family planning centres in France. Recent research from Bibia Pavard has shown the importance of transnational exchange in the creation of the French Family Planning Movement. She has underlined how foreign experience of birth control, especially that in the US, helped to 'legitimate the cause of birth control in France.46 
This last section extends Pavard's work by showing how the British case constituted a resource and model for family planning in France. In the French pronatalist and familialist context, where contraception and public propaganda on birth control were banned, approaching the subject of birth control through the lens of the debate in Britain and the US facilitated the advent of a similar but adapted debate in France. Similarly, recent research has shown the influence of British doctors in the contraceptive training of doctors in Spain and Poland. ${ }^{47}$

British women doctors represented a channel of birth control information for French doctors from 1935 onwards. The first French birth control clinic, a clandestine experiment that lasted no more than two years, opened in the city of Suresnes in 1935 due to the common efforts of Dr Jean Dalsace, an activist in the Association d'Etudes Sexologiques, who became a loyal supporter of birth control and contraception in France and one of the major figures of the movement, and Henri Sellier, the Popular Front's minister for public health. Henri Sellier built a garden city based on social hygiene in Suresnes, where they established a prenuptial clinic and distributed information on sex education and diaphragms as a way to prevent illegal abortions. As early as 1931, Edith How-Martyn from the Birth Control International Information Centre replied to a letter from Dalsace asking her for information on birth control, and she forwarded him literature on the subject. In 1934, one year before opening his birth control clinic in Suresnes, Dalsace wrote to Gladys Cox and Margaret Jackson, asking them to describe their work in the clinic and on infertility, as he was keen to learn more about this issue. Jackson replied, explaining that she referred patients with possible sterility to hospitals and private medical centres. The aim of birth control clinics is providing advice on birth control, [as] such information could not be found in other medical organisations. ${ }^{4}$ Dalsace seems to have used this material not only as a resource for opening 'his' centre in 1935 - little is known about the history of this clinic $^{49}$ - but also for documenting his 1934 conference paper, entitled 'Birth Control', for the Groupe d'Etudes Philosophiques et Scientifiques pour l'Examen des Tendances Nouvelles. He started his talk by expressing his reluctance to use the word 'birth control', a reluctance he felt not only towards the English expression but also due to its diverse translations in French. He argued that using 'control' meant the 'incursion of the State or the doctor or a third party into the couple's private 
intimacy. ${ }^{50}$ The various tentative translations into the French language were no better, in his view, which is why he would use 'birth control' in its English meaning and translation for lack of a better phrase. He emphasised the fact that due to the 1920 law he would not be able to present and explain birth control methods as such. He then offered a history of birth control and emphasised the leading role of Marie Stopes in Britain. He characterised Britain, a country generally depicted by the French as a 'hypocritical country', as honest with regard to sexual matters and praised its efficiency and simplicity in taking care of the issue through setting up birth control clinics. Britain was therefore presented as an example to follow, a country in which 'birth control is officially recognised and where it is perceived as a humanitarian charity," ${ }^{51}$ whereas France was portrayed as a fickle country where birth control was widely practised but health authorities refused to take the issue under their care.

After the Second World War, and while creating the Mouvement Français pour le Planning Familial, French leaders of the movement such as Lagroua Weill-Hallé and Jean Dalsace made numerous references to Britain, presenting it as an example of the standard towards which modern medicine should strive. In 1953, in her article published in La Semaine Médicale, Lagroua Weill-Hallé presented the work carried out by US and UK family planning centres. She also tried to translate 'planned parenthood' into French, settling on 'maternité dirigée' (directed motherhood), a clear refocus from parenthood to motherhood. She immediately refined her argument, emphasising that it meant giving parents the opportunity to have a wanted child. This labelling attests to Lagroua Weill-Hallés desire to adapt the American and British experience to the particular circumstances of the French familialist and pronatalist climate. Indeed, to gain public support, especially from the medical profession, Lagroua Weill-Halle had to distance herself from neo-Malthusianism and instead align her rhetoric with mainstream familialist language, which was dominant not only within the Ordre des Médecins - the medical association of doctors created during the Vichy Regime - but also among population experts such as the demographer Alfred Sauvy, director of the National Institute for Demographic Studies, who was against any change to the 1920 law. Lagroua Weill-Hallé called for a revision of the 1920 law and explained that such a stance was 'not incompatible with a pronatalist policy. ${ }^{52}$ She presented the US and the IPPF as sources of 
inspiration for her movement, explaining that she had first discovered birth control clinics while travelling in the US with her husband in 1947 and was introduced to the subject by Abraham Stone. She equally referred to the Cheltenham conference as a founding moment where different countries gathered to acknowledge the advance of 'maternité dirigéé.

This was not Lagroua Weill-Hallés only reference to the foreign context. In her speech at the Académie des Sciences Morales et Politiques on 'considerations about voluntary motherhood', advocating the dissemination of birth control information as a tool to prevent abortions, she underlined that 'opposition to birth control is unjustifiable in a country which flatters itself on permitting the individual the free exercise of his conscience. In other countries such as the US, Britain, Holland and Sweden, birth control has been accepted as a social measure. ${ }^{53}$ By comparing the French situation with that of other countries, she implicitly highlighted the French backwardness in terms of reproductive politics, and she called for a change in the law. This speech was reported in the bulletin of the IPPF, revealing that the French situation was closely followed by the IPPF's members who therefore considered France as a probable future member of the movement. Lagroua Weill-Hallé published a book in 1958 entitled La liberté de la conception à l'étranger (The Freedom of Conception in Foreign Countries), which described all the contraceptive methods available in family planning centres in the US and Britain, the Netherlands and Sweden based on the documentation provided by the FPA and that she acquired on a study trip she made to Britain and Netherlands. Moreover, Lagroua Weill-Hallé recognised the key role played by the British FPA in the creation of the French movement in a letter addressed to Margaret Pyke in 1961 about the inauguration of the first centre of the Mouvement Français pour le Planning Familial in Paris: 'We never forget to tell the numerous members of the movement that if British members did not contribute through their concern, help and generosity towards our work, we wouldn't have been able to develop the movement in France. In particular, our doctors know the pivotal role you played in helping them satisfy their medical prescriptions. ${ }^{54}$

Following the Bac affair, birth control loomed large in the French press, and here again supporters of its use took Britain as a model. In 1961, the journalist Madeleine Franck published a series of articles in France Soir, relating a trip she undertook in Britain. Entitled 'Birth 
Control: Yes or No', this series was aimed at providing the reader with accurate information to answer a set of specific questions:

A husband and wife, can they and ought they to choose the most propitious moment for the birth of a child? Would it be desirable in everybody's interest, that scientific means be legally supplied to French women - as they are to English, American, Dutch and Scandinavian women - to control and plan their birth rate? Ethically, by making birth control easier, shall we take a step forward in civilisation, or on the contrary, a step backwards? If the sale of contraceptive pills were authorised in France, as has just been done in England, would you approve $?^{55}$

To answer this question Madeleine Franck met Jean Medawar from the Family Planning Association in London. Jean Medawar was the joint editor of Family Planning from 1959 and had joined the FPA executive in 1960. In addition, she was a receptionist at the Islington Family Planning Clinic. Married to the Nobel Prize winner for medicine, Peter Medawar, the couple were the parents of four wanted children, born when the couple decided. The emphasis was therefore placed on the advantage of birth control for increasing the birth rate, aligning the article with the familialist policy in France. In Medawar's view, deliberate planning merely encouraged married couples to want several children since spacing the children prevented the wife's feelings of exhaustion and anxiety. ${ }^{56}$ The journalist also emphasised the human dimension of the work carried out at the clinic. She interviewed Dr Rosalie Taylor, a psychosexual counsellor, who worked at the FPA and took an 'interest in the patient's personality'. Taylor tried to understand why some patients did not return for follow-up appointments and why some gave up the recommended methods. By emphasising how Taylor dealt with sexual difficulties within marriage, the journalist showed that the work of an FPA clinic was not restricted to prescribing contraception mechanically but entailed the treatment of sexual disorders and fears that could affect a happy marriage. The British experience was therefore put forward as a positive model that increased the birth rate - as the baby boom testified - and helped the stability of the marital relationship.

Besides the explicit example that Britain offered for the MFPF, letter exchanges between French and British doctors suggest that French doctors, Dalsace in particular, asked female British doctors for 
information on contraception. In December 1954, Vera Houghton, executive secretary of the IPPF, sent him leaflets explaining the aims of the federation and its first annual report. The same letter also testifies to a meeting between Dalsace and Cecily Mure in Paris. While the content of the meeting is not mentioned, this meeting without doubt provided the latter with practical insights into the running of family planning clinics. Leaflets on family planning were sent to Lagroua WeillHallé upon request in $1956 .{ }^{57}$ Arlette Fribourg from Paris also wrote to Eleanor Mears asking for information about the contraceptive pill in 1961: 'I wish to know if they are now obtainable in your department of the FPA and experience you have already in England about this method. In case you can send contraceptive pills, can you tell me if they are the same (same product or pharmaceutical product) as in the USA? ${ }^{58}$ The same year, the FPA granted permission to Catherine Valabrègue, secretary of the French association, to make a French version of the 24-minute film Birthright made by the FPA in $1958 .{ }^{59}$ This film presented the work of the British clinics and advocated for the need to develop birth control in developing countries as a means to fight poverty. It was divided into six sections: 'wanted' children, infertility, pre-marital counselling, gynaecological problems, contraception and concern for global population growth. The film was made available for members of the association and was screened during training sessions. Therefore, the film provided the French audience with all the necessary information to understand family planning and the initiatives developed in Britain to help couples have a child when they wanted one.

Training and visits to Britain by many French doctors, as individuals or members of the Mouvement Français pour le Planning Familial, also demonstrate the influence of British doctors on French doctors. In 1947, Dr Suzanne Képès, a gynaecologist who was well versed in psychiatry, undertook a trip to London and received training in contraception at one of the family planning clinics. Following this trip, convinced of the necessity of contraception, she started to import caps and diaphragms clandestinely to France and made numerous trips between the two countries for this purpose. ${ }^{60}$ She would later explain that, similarly to the reason behind the creation of family planning clinics in Britain, the solution to unwanted pregnancy and the high level of illegal abortions was contraception: 'I threw myself into this fight with my own motivations. Something needed to be done, doing what was fair and 
right for women and men. ${ }^{61}$ In 1955, she met Lagroua Weill-Hallé and joined the association in 1956.

In 1957, the IPPF report for the region of Europe recognised the decisive role of the British FPA in helping the French medical body to develop family planning: 'The number of doctors from France who have called at the regional office, visited the headquarters of the FPA and seen over a Clinic is most encouraging. It indicates growing concern at the present situation in France where the 1920 law forbids any propaganda for birth control or the giving of advice on contraception. ${ }^{62}$ The same report stated that both Lagroua Weill-Hallé and Evelyne Sullerot had embarked on study trips to London. ${ }^{63}$ According to letters exchanged between British members, Lagroua Weill-Hallé visited the headquarters and shared her main problem with the French situation: 'to convince the doctors in France that family planning has positive aspects and is not designed to limit the population. ${ }^{64}$ Lagroua Weill-Hallé met with Helena Wright, whom she described as 'the champion of contraception in Britain', and learnt about the insertion and the placing of the occlusive pessary. ${ }^{65}$ In addition, she took back with her to France the books written by Helena Wright and Joan Malleson. She later wrote back to the headquarters, thanking them for having given a wide range of documentation to Evelyne Sullerot.

During the first decade after the creation of the Mouvement Français pour le Planning Familial, such a trip seemed to be an initiation ritual for new doctors joining the movement. In 1959, Yvonne Dornes and Catherine Valabrègue spent forty-eight hours in London and met Helena Wright, Joan Rettie and Cecily Mure. They were taught at the FPA headquarters in 'a room adjacent to a laboratory where toads frolicked in a small tub. Toads were used by the FPA to detect pregnancy, while in France rabbits were used for the same purpose. ${ }^{66}$ French doctors were being instructed alongside a diverse audience of foreign doctors and nurses. Doctors were asked to train in the fitting of contraceptive devices by practising on the body model designed by Helena Wright. ${ }^{67}$ According to the testimony of Catherine Valabrègue, published in the journal of Maternité Heureuse, 'Helena Wright displayed great human empathy in her speech, which made her particularly fascinating. ${ }^{68}$ She regularly checked that her audience had followed her demonstration by asking whether they had any questions. She urged the doctors to be especially sensitive to the issues of 'adjustment of the 
patient to the contraceptive methods recommended' and of the followup appointment, usually one week after the initial fitting, during which the doctor ensured that the patient understood the functioning of the method and that she was satisfied with it. ${ }^{69}$

The French women doctors Le Sueur-Capelle, Boutet de Montvel and Kahn-Nathan made their way to London to take a practical internship at the family planning clinic in 1961 and $1962,{ }^{70}$ as did four French doctors in $1963 .^{71}$ Dr Elisabeth Aubény, a gynaecologist who would later become the president of the French Association of Contraception, reflected on her experience in London. In 1963, as a medical student in gynaecology, she did an internship at the Broca Hospital in Paris, where both Jean Dalsace and Raoul Palmer worked, specialising in issues around sterility. There, she discovered the idea of family planning. While she encountered deaths in her practice due to backstreet abortions, the condom was the only method she would recommend to her patients since it was permitted in France as a means to fight venereal disease. At Broca, Dalsace shared his interest in family planning and suggested that she should take a training course in London. Aubény, along with her two female gynaecologist interns, went to London and were received by the IPPF. As she later recalled, they were very impressed by the efficiency of the organisation. They were sent to visit birth control clinics and were amazed by the large number of patients that were seen in a short period. ${ }^{72}$ They learnt how to insert a cap along with contraceptive jelly and practised on Helena Wright's pelvic body model. They bought caps and diaphragms and clandestinely brought them back to Paris. They also noticed that some birth control clinics prescribed the pill to their patients for a trial period. Aubény was shocked, as she recalled that when the pill arrived on the French market, she was unwilling to prescribe it, explaining that it was not how medicine was taught to us during our study years. The duty of the doctor is to treat diseases that endanger life. The doctor offered a diagnosis, established a treatment. In the case of contraception, all the classical schemes were shattered. ${ }^{73}$ Having had the opportunity to be trained in contraception and in how to insert a diaphragm, these women doctors knew they were part of a broader movement. They travelled back from London 'satisfied and proud, conscious of bringing to their female patients a contraceptive technique, admittedly restrictive and not entirely reliable, but a technique that they would own and 
practise themselves', as Aubény recalled a posteriori ${ }^{74}$ In France, they would follow the exact procedures they had learnt in Britain to teach their private patients, applying the knowledge they gained in their own daily practice.

The inspiration and training provided by the British model was not limited to contraception but also extended to psychosexual counselling. Suzanne Képès, who was in charge of the training of doctors at the MFPF from 1965, suggested in 1968 that doctors working with the MFPF should be trained in psychology, based on the seminar training that the FPA offered to its doctors - the Balint seminar. ${ }^{75}$ Képès had attended a training seminar at the Tavistock Clinic under the supervision of Balint in 1966. In 1968, she contacted Dr Sara Abel, a FPA trainee in Balint's technique, to offer a report on her work. The idea was to share her experience with members of the MFPF to provide basic information on the method. The FPA doctors who underwent this training were handling a wide range of issues, including sexual disorders such as vaginismus, frigidity and non-consummation, which were issues familiar to French doctors. She suggested setting up similar seminars in which MFPF doctors could share and analyse their cases and gain input from each other. The Balint seminar, she suggested, could be delivered under the supervision of Dr Michel Sapir, a well-known psychiatrist and a follower of Balint with whom she collaborated regularly, Dr Main from London, and even, periodically, Balint himself. Suzanne Képès would be a loyal follower of Balint and apply his method for her entire career. In 1972, she wrote that in her view, Balint's legacy in the way medicine was practised would be greater than Freud's contribution. ${ }^{76}$

The Family Planning Association also provided French doctors with contraceptive products. Many letters from private doctors to the secretary of the FPA testify to this mailing of devices. By 1960, the FPA had noticed a dramatic increase in the numbers of French requests for contraceptive devices, as shown by a letter from the medical secretary of the FPA to Nelson-Barette:

During the past two years orders from patients in France for contraceptives have increased from the occasional one about every six months to an average of ten a day. During 1960, the total value of the orders was approximately 1000 (which includes an estimate for the last two weeks of December). The orders are largely for Durex Dutch caps (on which the profit on the cost prices is $71.4 \%$ ) and duracreme on which the profit on cost price is $50 \% .^{77}$ 
Finally, presentations by British members at conferences organised by the French body and contributions to French publications also support the hypothesis of a decisive British influence. As early as 1955, in the special issue of Gynécologie Pratique on birth control, Horder, president of the FPA, was asked by Dalsace to write an article on family planning in the UK. In June 1960, Cecily Mure was invited by Maternité Heureuse to take part in a publicity weekend in Paris in favour of family planning. She spoke at two meetings about the work done by the FPA in Britain. ${ }^{78}$ In November 1963, Eleanor Mears gave a paper at a conference organised by Dalsace and Palmer on contraception. She also spent some time with them and with Lagroua Weill-Hallé while she was in Paris. $^{79}$

\section{Conclusion}

From the mid-1930s, British women doctors actively campaigned to add birth control and contraception to the list of legitimate medical specialties. This important work, carried out on a national scale, was also pursued on an international one. They were instrumental in recreating a transnational movement for birth control, changing to calling it planned parenthood at the dawn of the Second World War, and continuing afterwards. While male scientists were highly visible at the first postwar international conference (1948) dedicated to this subject mirroring the stratification of the field of medicine and the fact that men seemingly held the positions of prestige - British women doctors were nevertheless very influential. Working behind the scenes, they took up the practical and organisational tasks of running the event and liaised with different individuals to build a transnational movement for planned parenthood. While often overlooked, this type of work was essential and significant in shaping the aims of this new alliance. During this international conference and those that followed, contraception became increasingly defined as a human right.

Women doctors' new position within medical circles at both national and international levels made their knowledge particularly attractive to foreign doctors seeking accurate knowledge on contraception. It is thus unsurprising that French doctors turned to their British counterparts to gain insight into family planning issues. In the French national context, where the advertisement of and recourse to birth control methods were prohibited, the experience of British doctors and their 
expertise on contraception constituted a useful and significant example to rely upon. By writing letters, attending training sessions and inviting British women doctors to meetings, French medical circles found the perfect example of a well-organised, efficient family planning movement where scientific considerations replaced moral arguments. Therefore, British women doctors played a pivotal role in the creation of the family planning movement in France and the transfer of knowledge was a decisive tool for implementing family planning services in France.

\section{Notes}

1 Parts of this chapter appeared in Medical History: see Rusterholz, 'English women doctors'

2 Bashford, Global Population.

3 Wellcome Collection, London, PP/CPB/C.2, 'Birth Control International Information Centre'.

4 Butler Library, University of Columbia, New York, Margaret Sanger papers, microfilm, Series III, Collected Document Series, Subseries II, Organisation and Conference, 'Birth Control International Information Centre'.

5 Wellcome Collection, London, PP/EPR/F.1/1:Box 5, 'World-wide birth control an appeal.

6 Wellcome Collection, London, PP/EPR/F.1/1:Box 5, 'List of correspondents.

7 M. Fielding (ed.), Birth Control in Asia: A Report of a Conference Held at the London School of Hygiene \& Tropical Medicine, November 24-5, 1933 (London: Birth Control International Information Centre, 1935), p. 11.

8 On the relationship between India and BCIIC see chapter 2 in S. Hodges, Contraception, Colonialism and Commerce: Birth Control in South India, 1920-1940 (Aldershot: Ashgate, 2008), pp. 47-75.

9 Fielding, Birth Control in Asia, p. 79.

10 Ibid., p. 80.

11 Wellcome Collection, London, PP/CPB/C.2, 'Birth Control International Information Centre, 1936'

12 Ibid.

13 Ibid.

14 Ibid.

15 For the rhetoric of rationalisation see Marks, Sexual Chemistry, p. 21.

16 On the subject of population explosion and its connected fears see Bashford, Global Population; Connelly, Fatal Misconception. 
17 S. Kling, 'Reproductive health, birth control and fertility change in Sweden, circa 1900-40', The History of the Family, 15:2 (2010), pp. 161-73.

18 Wellcome Collection, London, SA/FPA/A10/10, IPPF Conferences 1946-66, 'Letter from Elise Ottesen-Jensen to Joan Malleson, 10 July 1946'.

19 Women's Library, London School of Economics, London, 8SUF/B/130, 'Interview with Helena Wright'.

20 Women's Library, London School of Economics, London, 8SUF/B/149, 'Interview with Helena Wright'.

21 Wellcome Collection, London, PP/EFG/A.46 Griffith: Publication on NBCA/FPA 1930s-40s, 'Proceedings of the International Congress on Population and World Resources in relation to the Family, August 1948, Cheltenham England', p. 8.

22 The London eugenics leader Carlos Paton Blacker and the president of the British FPA Thomas Jeeves Horder, who presided over the Asian conference in 1933, were also both present.

23 Women's Library, London School of Economics, London, 8SUF/B/149, 'Interview with Helena Wright'.

24 Wellcome Collection, London, PP/EFG/A.46 Griffith: Publication on NBCA/FPA 1930s-40s, 'Proceedings of the International Congress on Population and World Resources in relation to the Family, August 1948, Cheltenham England', p. 109.

25 Ibid., p. 111.

26 Ibid., p. 111.

27 Women's Library, London School of Economics, London, 8SUF/B/149, 'Interview with Helena Wright'.

28 Wellcome Collection, London, PP/EFG/A.46 Griffith: Publication on NBCA/FPA 1930s-40s, 'Proceedings of the International Congress on Population and World Resources in relation to the Family, August 1948, Cheltenham England', p. 244.

29 Women's Library, London School of Economics, London, 8SUF/B/130, 'Interview with Helena Wright'.

30 Butler Library, University of Columbia, New York, Margaret Sanger papers, microfilm, Series III, subseries 1 correspondence, 'Letter from Helen Donington to Margaret Sanger, 10th November 1948'.

31 Butler Library, University of Columbia, New York, Margaret Sanger papers, microfilm, Series III, subseries 1 correspondence, 'Letter from Margaret Sanger to Helen Donington, 13th January 1949'.

32 Butler Library, University of Columbia, New York, Margaret Sanger papers, microfilm, Series III, subseries 1 correspondence, 'Letter from Helen Donington to Margaret Sanger, 28th January 1949’. 
33 On these tensions see D. H. Linder, 'Crusader for Sex Education': Elise Ottesen-Jensen (1886-1973) in Scandinavia and on the International Scene (Lanham, MD: University Press of America, 1996), pp. 175-82.

34 V. Houghton, 'Report of meeting of International Committee on Planned Parenthood', The Eugenics Review, 43:3 (1951), p. 141.

35 Wellcome Collection, London, SA/FPA/A10/8, 1955-66 IPPF, 'Letter from Helena Wright to medical members of the IPPF's governing body, 3 March 1955': 'I proposed the setting-up of a medical sub-committee of doctors only, for the purposes outlined in IPPF 35(L). The governing body gave its sanction and at the second meeting of the Medical Sub-Committee I was appointed Chairman.'

36 Bibliothèque interuniversitaire de Santé, Paris, Fonds Dalsace-Vellay, Vellay 9.5 IPPF, 'The IPPF Medical Committee', in News of Population and Birth Control, CXVII (1963).

37 Bibliothèque interuniversitaire de Santé, Paris, Fonds Dalsace-Vellay, Vellay 9.5 IPPF, 'First annual report, 29 November 1952/31 August 1953'.

38 Wellcome Collection, London, SA/FPA/A10/8, 1955-66 IPPF, 'International Planned Parenthood Federation region for Europe near East and Africa, Minutes of the Fifth Meeting of the Regional Council, November 1960'.

39 Wellcome Collection, London, SA/FPA/A10/8, 1955-66 IPPF, 'Letter from Elstone Secretary of the IPPF to Helena Wright, 8 November 1963'; 'Letter from Elstone Secretary of the IPPF to Mary Pollock, 20 April 1966'.

40 Wellcome Collection, London, PP/EFG/A.46 Griffith: Publication on NBCA/FPA 1930s-40s, 'Proceedings of the International Congress on Population and World Resources in relation to the Family, August 1948, Cheltenham, England'.

41 Bibliothèque interuniversitaire de Santé, Paris, Fonds Dalsace-Vellay, Vellay 9.5, 'First annual report, 29 November 1952/31 August 1953, IPPF'

42 Ibid.

43 Wellcome Collection, London, SA/MWF/K.8/12, 'Report on the 11th Congress Vienna, 24-25 June 1968'.

44 Bashford, Global Population, p. 330.

45 See Pavard, 'Si je veux, quand je veux'; Bard and Mossuz-Lavau, Le planning familial.

46 B. Pavard, 'Du birth control au planning familial (1955-60): un transfert militant', Histoire@Politique, 18:3 (2012),pp. 162-78.

47 See T. Ortiz-Gómez and A. Ignaciuk, 'The fight for family planning in Spain during late Francoism and the transition to democracy, 1965-79', Journal of Women's History, 30:2 (2018), pp. 38-62.

48 Bibliothèque interuniversitaire de Santé, Paris, Fonds Dalsace-Vellay, Dalsace 11.1. 
49 Ibid.

50 Author's own translation: 'L'incursion de l'Etat, du docteur ou de tout autre personne dans l'intimité du couple', in Bibliothèque interuniversitaire de Santé, Paris, Fonds Dalsace-Vellay, Dalsace 13, "Birth control”, paper presented at the Groupe d'études philosophiques et scientifiques pour l'examen des tendances nouvelles, 15 février 1934'.

51 Author's own translation: 'le birth control y est officiellement reconnu et perçu comme nécessaire d'un point de vue humanitaire et charitable', in Bibliothèque interuniversitaire de Santé, Paris, Fonds Dalsace-Vellay, Dalsace 13, “"Birth control”, paper presented at the Groupe d'études philosophiques et scientifiques pour l'examen des tendances nouvelles, 15 février 1934'.

52 Author's own translation: 'n'est pas incompatible avec une politique nataliste', in Bibliothèque interuniversitaire de Santé, Paris, Fonds DalsaceVellay, Dalsace 11.1. M.-A. Lagroua Weill-Hallé, 'Le contrôle des naissances et la loi française de 1920', La semaine médicale, supplément de la semaine des hôpitaux (22 mars 1953).

53 Author's own translation: 'L'opposition au contrôle des naissance est injustifiable dans un pays qui se flatte de permettre le libre exercice de la conscience. Dans d'autres pays comme les Etats-Unis, l'Angleterre, la Hollande ou la Suède, le contrôle des naissances est accepté comme une mesure sociale', in Bibliothèque interuniversitaire de Santé, Paris, Fonds Dalsace-Vellay, Dalsace 11.1. Lagroua Weill-Hallé, 'Considération sur la maternité volontaire, 15 December 1954'.

54 Wellcome Collection, London, SA/FPA/A21/8 France 1951-67, 'Letter from La maternité Heureuse, MFPF, 31 October 1961 to Mrs Pyke'.

55 Wellcome Collection, London, SA/FPA/A21/8 France 1951-67, M. Franck, 'Contrôles de naissances oui ou non?' in France Soir (March 1961).

56 Ibid.

57 For exchange of information between Britain and France see Bibliothèque interuniversitaire de Santé, Paris, Fonds Dalsace-Vellay, Vellay 9.5 IPPF. 'Letter from Vera Houghton'.

58 Wellcome Collection, London, SA/FPA/A21/8 France 1951-67, 'Letter from Arlette Fribourg to Eleanor Mears, 25 April 1961'.

59 Wellcome Collection, London, SA/FPA/A21/8 France 1951-67, 'Letter from Freda Parker to Mademoiselle D. Jeanson, January 20th 1961'.

60 B. Philippe, 'Suzanne Képès, une femme d'exception', Le Carnet PSY, 6:101 (2005), p. 36.

61 Author's own translation: 'Je me suis jetée dans cette bataille avec mes propres motivations. Quelque chose devait être fait. Je voulais faire quelque 
chose de juste pour les femmes et les hommes'. S. Képès, Du corps à l'âme, entretiens avec Danielle M. Lévy (Paris: L’Harmattan, 1996), p. 102.

62 Wellcome Collection, London, SA/FPA/A10/8 1955-66 IPPF, 'Report of International Planned Parenthood Federation and accounts for the region for Europe, March 1957'.

63 They were not alone. According to a report from the FPA, Dr Pierre Bertrand, Dr Geneviève Hall, Dr Mato Medeau, Dr Elizabeth Palmer, Mrs Pechabrier (Ministry of Health and Education), Dr Yves Peninou, Evelyne Sullerot and Dr and Mrs Lagroua Weill-Hallé were all trained in 1956. See Wellcome Collection, London, SA/FPA/A10/8 1955-66 IPPF.

64 Wellcome Collection, London, SA/FPA/A10/8 1955-66 IPPF, '5th September 1956, Visit of Dr Weill-Hallé to headquarters'.

65 M.-A. Lagroua Weill-Hallé, La prescription contraceptive (Paris: Librairie Maloine, 1968), 11.

66 On pregnancy testing see J. Olszynko-Gryn, 'The demand for pregnancy testing: the Aschheim-Zondek reaction, diagnostic versatility, and laboratory services in 1930s Britain', Studies in History and Philosophy of Science Part C: Studies in History and Philosophy of Biological and Biomedical Sciences, 47 (2014), pp. 233-47.

67 On the body model see Chapter 1.

68 Author's own translation: 'Le Docteur Wright témoigne dans ses propos d'un sens humain qui la rend particulièrement captivante'. C. Valabrègue, '48 heures à Londres', in La Maternité Heureuse, Bulletin trimestriel d'information, 9 (1959), p. 11.

69 Ibid.

70 Wellcome Collection, London, SA/FPA/A21/8 France 1951-67, 'Letter from S. Le Sueur Cappel to E. Mears, 11 November 1961': 'I came back to Versailles very happy from my too short sejour in England. I thank you very much for the charming welcome I have found wherever I have been received and all the centres I have seen, [they] were very interesting for me.'

71 Wellcome Collection, London, SA/FPA/A10/8 1955-66 IPPF, 'Letter to Joan Rettie, 8 November 1963': 'Herewith the usual forms and literature for the four who will be attending the lectures and demonstration session in London on Tuesday 12 November: Dr Chatelin [male doctor] Dr Houdville [male doctor], Dr Jacqueline Cahen-Wolff, Dr Branle.'

72 Private phone interview with Dr E. Aubény, 25 September 2017.

73 'Ce n'était pas comme ça qu'on nous enseignait la médecine durant nos années d'études. Le devoir du médecin est de traiter les maladies qui mettent en danger la vie humaine. Le médecin offre un diagnostique, établit un traitement. Dans le cas de la contraception, tous les schémas 
classiques étaient bouleversés' in E. Aubény, 'La contraception à l'hôpital December 1988', private archive. I would like to thank Dr Aubény for having kindly shared her material with me.

74 'satisfaites et fières, conscientes de ramener à leurs patientes une techniques de contraception, certes contraignante et pas entièrement fiable, mais une technique qu'elles allaient pouvoir posséder et utiliser ellesmêmes' in E. Aubény, 'La contraception, Histoire d'une liberté pour les femmes. Principes et Réalités', paper presented at Assises Nationales des Sages-Femmes, Nantes, 20 May 2011, private archive.

75 Bibliothèque interuniversitaire de Santé, Paris, Fonds Dalsace-Vellay, Dalsace 11.5, 'Formation psychologique des médecins en Angleterre, 30 September 1968'.

76 Archives du féminisme, Anger, Fond Képès 19AF28: 'S. Képès, Aspects relationnels de la consultation de contraception, 14 January 1972'. Many thanks to Fabrice Cahen who kindly collected the requested documentation for me.

77 Wellcome Collection, London, SA/FPA/A10/8 1955-66 IPPF, 'Letter from Mrs Wintersgill to Mrs Nelson-Barette, 13 December 1960'.

78 Wellcome Collection, London, SA/FPA/A13/85B, 'The FPA Walworth Women's Welfare Centre, annual report 1960'.

79 Wellcome Collection, London, SA/FPA/A10/8 1955-66 IPPF, 'Letter from medical secretary Mears to Mr and Mrs Dalsace, 15 November 1963' and 'Letter from Mears to Raoul Palmer, 15 November 1963'; 'Letter from Mears to Lagroua Weill-Hallé, 15 November 1963’. 